\title{
Monika Borowska
}

UNIWERSYTET PAPIESKI JANA PAW ŁA II W KRAKOWIE

DOI: HTTP://DX.DOI.ORG./I0.15633/9788374389327.08

\section{Psychologiczne tendencje w religijności osób żyjących w związkach niesakramentalnych}

Psychological tendencies in the religiosity of people living in non-sacramental relationships

\section{STRESZCZENIE}

Studium stanowi analizę psychologicznych parametrów religijności osób wierzących i praktykujących, niemogących jednocześnie korzystać z pełni życia religijnego (uczestniczyć w życiu sakramentalnym) skutkiem dobrowolnej decyzji pozostawania w kolejnym związku małżeńskim bez stwierdzenia nieważności pierwszego, zawartego w Kościele. Obserwowane w praktyce psychologicznej zderzenie potrzeby pełnego życia religijnego przy jednoczesnych przeszkodach w jego realizacji sugerują istnienie określonych tendencji w psychologicznej realizacji religijności, badanej tak z perspektywy praktyki psychologicznej, jak i duszpasterskiej. Zadaniem pracy jest poszukiwanie odpowiedzi na pytanie: czy w religijności osób żyjących w związkach niesakramentalnych istnieją specyficzne tendencje? A jeżeli tak, to jaki jest ich obraz? Podstawą teoretyczną badań jest poznawczo-rozwojowa 
koncepcja religijności Czesława Walesy. W badaniach zastosowano kwestionariuszową metodę diagnostyczną, ujmującą religijność wg ośmiu parametrów. Badaniami objęto 19 osób, członków Duszpasterstwa Niesakramentalnych Związków Małżeńskich. Uzyskane wyniki sugerują istnienie ambiwalentnych lub negatywnych tendencji w zakresie:

1. finalnej perspektywy życia,

2. subiektywnego stosunku do nakazów Kościoła,

3. wyborów zasadniczych priorytetów w relacji/odniesieniu do Boga.

Słowa kluczowe: religijność, parametry religijności, związek niesakramentalny, tendencje ambiwalentne, tendencje negatywne.

\section{ABSTRACT}

The study analyses psychological parameters of religiosity of believers and practitioners who do not fully participate in sacramental life as a result of a voluntary decision to be in an informal relationship, without having annulled the previous marriage ordained by the Church. The need for a full religious life with experiencing simultaneous obstacles in its implementation suggests specific tendencies in one's religiosity which is studied from psychological and pastoral perspective. The goal of this study is to seek the answer to questions: Are there specific tendencies in the religiosity of people living in non-sacramental relationships? And if so, what are they characterized by? The theoretical basis of the research is the cognitive and developmental concept of religiosity by Walesa. The study involved examining 19 members of the pastoral care of non-sacramental marriages association using a questionnaire which captures religiosity in eight parameters. The obtained results suggest the existence of ambivalent or negative trends in the following areas:

1. final perspective of life,

2. subjective attitude towards the Church's precepts,

3. basic priorities in relation to God.

Keywords: religiosity, religiosity parameters, non-sacramental relationship, ambivalent tendencies, negative tendencies. 


\section{Wstęp}

Artykuł powstał na gruncie nauk o rodzinie w odniesieniu do szerokiej problematyki miejsca religijności w życiu rodzinnym i małżeńskim. Jednym z podjętych w jej ramach zagadnień szczegółowych jest religijność małżonków wierzących i praktykujących, trwających jednocześnie w związku niesakramentalnym. Z perspektywy nauczania Kościoła można by przyjąć, że jeżeli ktoś wierzący świadomie żyje w permanentnym stanie grzechu ciężkiego, to tym samym decyduje się na pozostawanie poza samym Kościołem, a może także poza religijnością. Coraz częściej jednak obserwujemy czynny i liczny udział wiernych będących w takiej sytuacji w organizowanych dla nich formach działań duszpasterskich. Sugeruje to potrzebę i jednocześnie gotowość do życia religijnego mimo istniejących przeszkód. W centrum dociekań stoi więc pytanie o ewentualną specyfikę tak przebiegającego życia religijnego, skoncentrowaną na aspektach treściowych ich religijności.

Za wyjściową koncepcją rozwoju religijności Czesława Walesy (Walesa, 2005) przyjęto, że religijność to forma świadomej aktywności ludzkiej o wieloczynnikowych uwarunkowaniach. Niekorzystny jednostkowy układ niektórych z nich może jednak powodować, iż nie osiąga ona pożądanego kształtu pomimo pozytywnego potencjału oraz świadomej gotowości do jej realizacji. Czy rozwój religijności zostaje wówczas zahamowany? A jeżeli nie, to jakie są cechy tak realizowanej religijności i jaka jest jej funkcja regulacyjna?

Zasadniczo studium ma charakter psychologicznej analizy empirycznej, jego przedmiot zmusza jednak do uwzględnienia perspektywy duszpasterskiej. Autorka traktuje ją jako konieczną i stanowiącą jednocześnie treściowe wysycenie poddanych badaniu zmiennych psychologicznych. Podejście takie uzasadnia również interdyscyplinarność wyjściowego kierunku - nauk o rodzinie. 
W badaniach zestawieniu poddano wyniki pierwotnej wersji Kwestionariusza do Badania Religijności Czesława Walesy, zawierającej 176 itemów (Katedra Psychologii Rozwojowej KUL, 2014). Przebadano 19 osób członków Duszpasterstwa Niesakramentalnych Związków Małżeńskich. Należy zaznaczyć, że badani bardzo chętnie wzięli udział w badaniu, doceniając zainteresowanie ich życiem religijnym. W ich opinii dodatkowym atutem badań była sama metoda, którą ocenili jako wymagającą sporego zaangażowania, zmuszającą do pogłębionej refleksji, a także pobudzająca do uczenia się.

\section{Związki niesakramentalne z perspektywy nauczania Kościoła}

Kościół Katolicki naucza, że twórcą małżeństwa jest sam Bóg, który powołanie do małżeństwa wpisał w naturę mężczyzny i kobiety. Wiele osób, które wchodzą w sakramentalny związek małżeński często nie uświadamia sobie, że jego istota to nie tylko usankcjonowanie związku w obliczu Kościoła, ale przede wszystkim uświęcenie sakramentalne życia małżeńskiego, rozumianego jako wspólne przechodzenie przez życie zgodnie z nauczaniem Ewangelii. Stąd potrzeba żywej wiary, aby możliwe było wytrwanie w małżeństwie sakramentalnym, nawet wtedy, kiedy napotyka się trudności (Wermter, 2009, s. 5).

Powszechnie uważa się, że ogromny wpływ na nietrwałość współczesnych małżeństw (w tym też sakramentalnych) mają przemiany i procesy społeczne, które niejednokrotnie źle oddziałują na współczesną rodzinę (Góralczyk, 1995, s. 37-39). Wydaje się jednak, że zasadnicze przyczyny tego zjawiska są szersze i o wiele bardziej złożone i nie można lokować ich wyłącznie w sytuacji i zmianach zewnętrznych, dokonujących się we współczesnym świecie. 
Jednym z największych zagrożeń dla związków sakramentalnych wydaje się być kryzys wiary, owocujący osłabieniem lub wręcz brakiem trwałych religijnych wartości, w tym też powierzchownym podejściem do życia sakramentalnego. Jego konsekwencją jest najczęściej brak odpowiedzialności osób przyjmujących sakrament małżeństwa. Małżonkowie nierzadko nie zdają sobie sprawy, ze sakramentalne małżeństwo oznacza uświęcenie wspólnego życia do jego końca. Niestety, często w chwili podejmowania decyzji o ślubie kościelnym, zwraca się uwagę przede wszystkim na to, co zewnętrzne (opinia najbliższej rodziny, status bycia „pełnym” małżonkiem, presja środowiska). Są to wyraźne braki w samym przygotowaniu do małżeństwa sakramentalnego, które w konsekwencji znacznie osłabiają odpowiedzialność za podjętą decyzję (Ostrowski, 2011, s. 251). Problem owej odpowiedzialności jest najczęściej łączny: dotyczy tak samego odniesienia do przyjmowanego sakramentu, jak i w ogóle decyzji o małżeństwie. W tej sytuacji (i w obliczu doświadczanych w małżeństwie trudności) małżonkowie nie podejmują walki o przetrwanie sakramentalnego związku. Powszechnie praktykowany rozwód widzą jako najprostsze i jedyne rozwiązanie. Konsekwencją tego jest przekonanie, że ślub kościelny zawarli lekkomyślnie i niepotrzebnie. I tu dochodzimy do najważniejszej przyczyny niepowodzeń sakramentalnych związków małżeńskich - braku rozumienia istoty małżeństwa sakramentalnego, czyli uświęconej wspólnoty osobowej mężczyzny i kobiety, której celem winna być wspólna troska o doskonalenie wewnętrzne i o to, by stawać się codziennie dla siebie i dla potomstwa darem. To jednakże wymaga odpowiedniej formacji wewnętrznej w postaci świadomie i konsekwentnie kształtowanego stosunku do Boga, a skutkiem tego - do doniosłych spraw życia.

Analizy przeprowadzone przez Centrum Badania Opinii Społecznej, ukazujące polską religijność w trzech głównych wymiarach: wyznania wiary, praktyk religijnych oraz moralności, rzucają większe światło na ten problem. Wynika z nich, że jedna trzecia populacji uważa, że należy mieć wyraźne 
zasady moralne i nigdy od nich nie odstępować. Natomiast 40 proc. społeczeństwa to ci, którzy twierdzą, że należy mieć takie zasady, ale można od nich odstąpić w wyjątkowych sytuacjach, 20 proc. uznaje zaś, że mimo posiadania zasad moralnych spokojnie można od nich odstąpić w zależności od sytuacji. Najbardziej skrajna, prawie dziesięcioprocentowa grupa badanych uważa, że nie należy wiązać swojego postępowania określonymi z góry zasadami moralnymi, ale powinno się w zależności od sytuacji znajdować właściwe sposoby postępowania i zachowania. Ponadto prawie 60 proc. badanych źródeł tych zasad poszukuje przede wszystkim u siebie, twierdząc, że to, czym jest dobro i zło, powinno być przede wszystkim wewnętrzną sprawą każdego człowieka.

Gdy zaproponowano już konkretne ustosunkowanie się respondentów do zasad moralnych katolicyzmu, za najlepsze i wystarczające uznała je prawie jedna czwarta badanych. Natomiast jedna trzecia stwierdziła, że są słuszne, ale życie jest tak skomplikowane, że trzeba je uzupełnić innymi zasadami. Największą, bo prawie czerdziestoprocentową grupę, stanowili ci, którzy stwierdzili, że większość zasad moralnych katolicyzmu jest słuszna, lecz nie ze wszystkimi się zgadzają, a ponadto te, które są słuszne, na pewno nie wystarczają człowiekowi.

Z przeprowadzonych badań wynika, że zasady moralne katolicyzmu są trudne do zaakceptowania przede wszystkim w dziedzinie etyki, w tym szczególnie seksualnej. To tutaj widać rozbieżność codziennych wyborów Polaków z nauczaniem katolickim. Trzy czwarte respondentów uważa stosowanie środków antykoncepcyjnych za dopuszczalne. Tyle samo aprobuje współżycie seksualne przed ślubem, a ponad połowa badanych traktuje rozwód jako coś dopuszczalnego (Tutak, 2010, s. 108-112).

Moralność nie stanowi zatem bezpośredniego przejawu religijności, ale jest z nią w znacznym stopniu skorelowana. Aktualnie wśród Polaków określających się jako bardzo religijni 70 proc. przypisuje sobie jednocześnie najwyższą moralność, a wśród tych, którzy w swoim przekonaniu są głęboko 
moralni, trzy czwarte uważa się za bardzo religijnych. Natomiast w zakresie związków między moralnością a religijnością prawie trzy czwarte Polaków uważa, że religia nie musi uzasadniać słusznych nakazów moralnych (Boguszewski, 2014).

Osoby, którym rozpadło się małżeństwo sakramentalne, znajdują się w nowej, niełatwej rzeczywistości. Jak rozpad każdego związku, jest to czas ogromnej samotności i cierpienia. Często towarzyszy temu poczucie krzywdy i porażki życiowej, gdyż zawiodła osoba, w której tak bardzo pokładało się nadzieje. Bezpośrednio po rozwodzie rozwiedzeni czują się bardzo samotni (Góralczyk, 1995, s. 49-54). Pojawia się potrzeba bliskości drugiej osoby i przynależności, bycia kochanym i kochania. Potrzeba ta staje się w tym momencie silniejsza niż chęć przestrzegania Przykazań Bożych. Chęć ułożenia sobie lepszego życia jest o wiele silniejsza niż potrzeba przestrzegania Dekalogu, który nie pozwala na powtórny ślub przy ołtarzu (Grzybowski, 2008, s. 35). Rozwiedzeni najczęściej próbują naprawić sytuację i uniknąć błędów z pierwszego małżeństwa. Zawierają wtedy nowe związki, z konieczności niesakramentalne, w których przeszkody kanoniczne wiążą przynajmniej jedną ze stron.

Obecnie Kościół potwierdza swoją praktykę niedopuszczania do Komunii Świętej rozwiedzionych, którzy zawarli ponowny związek małżeński. Nie mogą oni być dopuszczeni do Komunii św. od chwili, gdy ich stan i sposób życia obiektywnie zaprzecza więzi miłości między Chrystusem i Kościołem, którą wyraża Eucharystia. Innym motywem duszpasterskim jest fakt, że dopuszczenie tych osób mogłoby wprowadzić innych wiernych w błąd lub powodować zamęt odnośnie do nauki Kościoła (FC 84'). Dlatego wierzący będący w takiej sytuacji świadomie ponoszą konsekwencje trwania w związku niesakramentalnym, pozostając jednak wiernymi Kościołowi. Jako ochrzczonych i wierzących trawi ich jednak

1 FC - Familiaris Consortio, adhortacja apostolska Jana Pawła II. 
często tęsknota za Bogiem, w sumieniu mają poczucie grzechu, a często i poczucie odrzucenia przez Boga.

Synodalna refleksja Karola Wojtyły dotycząca problematyki związków niesakramentalnych zaowocowała wzywaniem pasterzy i całej wspólnoty wiernych do okazania pomocy rozwiedzionym, do podejmowania z miłością starań o to, by nie czuli się oni odłączeni od Kościoła, skoro jako ochrzczeni powinni uczestniczyć w jego życiu. Papież apelował, by zachęcać te osoby do słuchania Słowa Bożego, do uczęszczania na Mszę Świętą, do wytrwania w modlitwie, do wychowywania dzieci w wierze chrześcijańskiej, ażeby w ten sposób z dnia na dzień wypraszali sobie u Boga łaskę. Nawoływał, by Kościół modlił się za nich, dodawał im odwagi i stawał się miłosierną matką, podtrzymując ich w wierze i nadziei (FC 84). Kościół nigdy o nich nie zapomniał, tym bardziej nie odrzucił, ani nie uważa za niegodnych (Tettamanzi, 2006, s. 6).

W ten sposób Jan Paweł II jasno wyraził troskę Kościoła o rodzinę w trudnych sytuacjach życia, mówiąc o tym, że trzeba się takimi osobami zaopiekować, zwracając się szczególnie o pomoc do osób duchownych:

(...) niech wiedzą duszpasterze, że dla miłości prawdy mają obowiązek właściwego rozeznania sytuacji. Zachodzi bowiem różnica pomiędzy tymi, którzy szczerze usiłowali ocalić pierwsze małżeństwo i zostali całkiem niesprawiedliwie porzuceni, a tymi, którzy z własnej, ciężkiej winy zniszczyli ważne kanonicznie małżeństwo. Są wreszcie tacy, którzy zawarli nowy związek ze względu na wychowanie dzieci, często w sumieniu subiektywnie pewni, że poprzednie małżeństwo, zniszczone w sposób nieodwracalny, nigdy nie było ważne (FC 84).

Dlatego dla duchownych, którzy prowadzą duszpasterstwo osób będących w związkach niesakramentalnych, niezwykle cenne są słowa Jana Pawła sugerujące, by osoby te zbliżały się do Miłosierdzia Bożego innymi drogami, 
a nie przez sakramenty pokuty i Eucharystii, do czasu aż nie spełnią wymaganych warunków (RP 34²), bo fakt zawarcia nowego związku powiększa jeszcze bardziej ciężar rozbicia, stawiając współmałżonka, żyjącego w nowym związku, jako tego, który publicznie i trwale cudzołoży (KKK 2384³).

Kościołowi bardzo zależy na rodzinie i małżeństwie, a tych, którzy pobłądzili, nie odtrąca, gdyż osoby, które żyją w związku cywilnym, posiadają te same zobowiązania, które wynikają ze złożonego przed Bogiem ślubowania. Powinni być i są odpowiedzialni za współmałżonka i dzieci, bardzo często jest tak, że małżonkowie po rozwodzie, a będący w nowym związku, starają się i pielęgnują np. wspólną modlitwę w rodzinie czy też przygotowanie dzieci do spowiedzi i Pierwszej Komunii Świętej. Kościół, jako Matka ludzi wierzących, próbuje przyjść z pomocą do tych wszystkich, „którzy źle się mają”. Mowa tutaj o wszystkich ochrzczonych, którzy najbardziej potrzebują troski i miłości, aby szukali Boga w modlitwie i aby wzrastali w wierze, czyniąc gesty miłosierdzia (Goszczyńska-Górska, 2004, s. 19-20).

\section{Struktura i stadia rozwoju religijności w świetle poznawczo-rozwojowej koncepcji Czesława Walesy}

Niewątpliwym walorem prac Czesława Walesy (jednego z najbardziej znaczących autorytetów polskich w tej dziedzinie) jest całościowe potraktowanie religijności, także jako zmiennej empirycznej (behawioralnej). Mamy więc psychologiczną teorię ją wyjaśniającą, opis stadialności oraz metodę służącą do pomiaru, a to umożliwia już stawianie pytań badawczych. Koncepcję Walesy potraktowano więc jako wyjściową, szukając

$2 \mathrm{RP}$ - Reconciliatio et poenitentia, adhortacja apostolska Jana Pawła II.

3 KKK-Katechizm Kościoła Katolickiego. 
odpowiedzi na pytanie: czy religijność osób wierzących i praktykujących, a niemogących jednocześnie korzystać z pełni życia religijnego (sakramentalnego) posiada jakieś specyficzne cechy? A jeżeli tak, to w czym się one zaznaczają? I dalej: jakie stąd wynikają wnioski dla praktyki psychologicznej i duszpasterskiej?

Według Walesy religijność stanowi jedną z potencjalnych form aktywności człowieka jako istoty wolnej, świadomej i rozumnej, a określają ją te stany i procesy psychiczne, które pozwalają na kształtowanie się świadomej, osobowej i pozytywnej relacji do Boga. W sensie psychologicznym odpowiadają za nią wzajemnie powiązane sfery funkcjonowania psychicznego: poznawcza (zawierająca komponenty poznawczo-informacyjno-orientujące), ustosunkowania (uczucia, motywy, wartości, czyli komponenty emocjonalno-motywacyjne) oraz działania (komponenty decyzyjno-ekspresyjno-wykonawcze). Komponenty te strukturalizują podstawowe elementy religijności. Walesa nadaje im rangi parametrów pierwszo-, drugo- i trzeciorzędowych i różnicuje tak w aspekcie formalnym, jak i treściowym. Zasadniczymi w rozwoju religijności są oczywiście parametry pierwszorzędowe. Autor wyróżnia ich osiem i porządkuje zgodnie z psychicznym, społeczno-kulturowym, osobniczym (przejawy ludzkiego ja) oraz treściowym aspektem religijności (Walesa, 2005, s. 19-20).

Kluczowe trzy pierwsze parametry mają charakter formalny i określają religijność jako zjawisko psychiczne. Powstały w oparciu o tradycyjny podział funkcjonowania człowieka na poznanie, ustosunkowanie i działanie. Są to:

- świa do mość religijna, czyli wiedza i przetwarzające ją myślenie. Jej moc regulacyjną możemy zaobserwować w każdej innej dziedzinie religijnej. Moc regulacyjna poszczególnych elementów świadomości jest tym większa, im bardziej pochodzi z wolnej woli, a nie z przymusu;

- uczucia religijne, pozostające w związku tak ze świadomością religijną, jak i z pozostałymi parametrami; 
- decyzje religijn e, czyli preferencje i wybory odnoszące się do życia religijnego tak w teraźniejszości, jak i w przyszłości, także eschatologicznej (również metadecyzje, które obejmują ciągle powtarzające się i ponawiane decyzje wcześniejsze).

Kolejne parametry formalne ujmują religijność jako zjawisko społeczno-kulturowe. Są to:

- więź z osobami wierzącymi - psychiczno-społeczny aspekt religijności, wymagający uspołecznienia oraz wyrazu kulturowego, czyli znaków, symboli, przeżyć, a także form działań realizowanych w wymiarze intelektualnym, społecznym i obyczajowym;

- praktyki religijne-aspekt realizacyjny religijności, koordynujący udział wszystkich poprzednich parametrów;

- moralność religijna, czyli zgodność lub niezgodność czynów z zasadami wiary, religijne kryteria dobra, religijne motywy działania. Dobro ujmowane jest tu personalistycznie, a sama moralność opiera się na decyzjach czy wyborach zgodnych lub niezgodnych z rodzajem więzi człowieka z Bogiem.

Religijność jako przejaw ludzkiego ja realizuje się w d oś w i a d c z e n i u reli g i jny m (kolejnym parametrze formalnym), opisanym jako „całościowe przeżycie z komponentami poznawczo-orientująco-informacyjnymi, uczuciowo-motywacyjnymi i decyzyjno-działaniowo-ekspresyjnymi” (Walesa, 2005, s. 39), a dotyczącym osobistego, bezpośredniego i naocznego ujęcia rzeczywistości nadprzyrodzonej, w połączeniu z przeświadczeniem pewności, oczywistości i prawdziwości tego doznania w swej intencjonalnej i pozytywnej relacji do Boga.

Ostatni z pierwszorzędowych parametrów ma charakter formalno-psychologiczny i zarazem treściowy. To for my wy znania wiary, a więc spontaniczne i pełne gotowości zachowania wynikające ż̇ywejłączności z Bogiem. Mają one charakter osobowy, a przejawiają się m.in. w sposobie odbioru, selekcji i przyswajaniu treści i informacji, których wspólnym mianownikiem 
są znaczenia religijne. Są to również sposoby manifestowania samej wiary. Formy wyznania wiary są szczególnie wyraźne w sytuacjach granicznych, a istotnym komponentem tego parametru jest gotowość do modlitwy i ofiary. Jednostkowy poziom i układ zasadniczych ośmiu parametrów określa osobniczy styl religijności, który dodatkowo może być oceniany przez układ parametrów pochodnych (drugo- i trzeciorzędowych).

Religijność w koncepcji Walesy jest potencjalna w rozwoju już od wczesnych okresów życia, podlega ogólnorozwojowym prawom konstrukcji i rozumiana jest jako efekt procesualnego przechodzenia od form elementarnych do coraz wyższych. Dochodzenie do religijności człowieka dorosłego jest konstrukcją ciągłą i etapową, a każdy etap posiada właściwą sobie specyfikę rozwojową. Głównym regulatorem jest poznanie, czyli sposób postrzegania, rozumienia i uzasadniania doświadczanej przez siebie rzeczywistości, ale także i siebie. Prawa i zasady realizacji etapów w rozwoju religijności są uniwersalne i przebiegają w tej samej kolejności, a strukturalizuje je (podobnie jak np. rozwój moralności, języka, działania) proces rozwoju poznawczego (por. Piaget, Kohlberg).

Stadia w rozwoju religijności uporządkowane są więc zgodnie ze stadiami rozwoju ogólnego:

- $0-1$ r.ż. - okres przedreligijny,

- 2-3 r.ż. - okres pierwszych przejawów religijności,

- 4-7 r.ż. - okres religijności magicznej,

- 7-11 r.ż. - okres religijności autorytarno-prawno-moralnej,

- 12-18 rż. - okres kształtowania się religijności autonomicznej,

- 18-24 r.ż. - okres autentyczności religijnej,

- 25-40 r.ż. - okres religijności realistyczno-stabilnej,

- 40-60 r.ż. - okres religijności spełnionej,

- powyżej 60 r.ż. - okres religijności człowieka starzejącego się (eschatologicznej). 
W rozwoju religijności Walesa szczególnie mocno podkreśla znaczenie aktywności własnej człowieka, wyrażającej się w aktywnym stosunku do rzeczywistości. Brak owej aktywności w rzeczywistości materialnej, symbolicznej i pojęciowej (np. poprzez samodzielne działanie, wyobrażenie, wnioskowanie, przemyślenie) uniemożliwia postęp w ramach kolejnych konstrukcji. W konsekwencji szczególnego znaczenia nabiera otwarcie się na doświadczenie oraz gotowość do aktywnego ustosunkowania względem jego treści.

Religijność jest więc zjawiskiem jednolitym i zintegrowanym, choć jednocześnie wieloaspektowym i urzeczywistniającym się poprzez konkretne przejawy życia psychicznego i społeczno-kulturowego (Rydz, 2014, s. 21). Należy zaznaczyć, że nie pozostaje ona w izolacji, lecz im bardziej staje się autentyczną i naczelną zasadą życia, tym bardziej pełni istotne funkcje regulacyjne w sferze poznawczej, motywacyjno-dążeniowej i decyzyjno-wykonawczej.

\section{Tendencje w religijności osób żyjących w związkach niesakramentalnych w świetle badań własnych}

Problem prezentowanego studium zawiera się w pytaniach: czy religijność osób wierzących i praktykujących, a niemogących jednocześnie korzystać z pełni życia religijnego (sakramentalnego) posiada jakieś specyficzne cechy? A jeżeli tak, to w czym się one zaznaczają? I dalej: jakie stąd wynikają wnioski dla praktyki psychologicznej i duszpasterskiej?

\section{Metoda}

W badaniach zastosowano narzędzie skonstruowane na gruncie wyjściowej teorii Czesława Walesy. Jest to pierwotna wersja Kwestionariusza do Badania 
Religijności, zawierająca 176 itemów, skonstruowana w 2014 roku na Katolickim Uniwersytecie Lubelskim (Katedra Psychologii Rozwojowej) przez Czesława Walesę i współpracowników. Kwestionariusz do badania religijności kontroluje badaną zmienną zgodnie z wyróżnionymi parametrami religijności (świadomość, uczucia, decyzje, więź ze wspólnotą osób wierzących, praktyki, moralność, doświadczenie, formy wyznania wiary). Metoda została uznana za przydatną do analizy jakościowej ze względu na większą liczbę ujmujących religijność itemów. Jest to metoda papierowa, składająca się ze 176 twierdzeń, gdzie na każdy parametr przypadają 22 twierdzenia. Zadaniem badanego jest ustosunkować się do nich w skali pięciopunktowej (odpowiedzi maksymalnej odpowiada zawsze pięć punktów). Metoda umożliwia obliczenie surowego wyniku globalnego i cząstkowych w poszczególnych parametrach religijności. Maksymalny wynik dla metody wynosi 880 , a minimalny 176 . Dla poszczególnych parametrów surowy wynik maksymalny wynosi 110, a minimalny 22 . Do skali dołączony jest klucz przeliczeniowy. Metoda opracowana jest dla kobiet i dla mężczyzn. Uzupełnieniem metody jest metryczka zawierająca dane demograficzne badanych: wiek, płeć, aktywność zawodowa, potomstwo, uprawiany zawód, zainteresowania, trudne wydarzenia życiowe, życiowe plany na przyszłość.

Metoda funkcjonuje obecnie w wersji skróconej jako Test Struktury i Poziomu Religijności, zawierający 40 najbardziej trafnych dla każdego parametru twierdzeń (po pięć na każdy z ośmiu parametrów). Dane odnośnie do konstrukcji testu i jego wskaźników psychometrycznych zostały opublikowane w „Polish Psychological Bulletin” (Rydz, Walesa, Tatala, 2017, s. 20-27).

\section{Sposób oceny i analizy wyników badania}

Zgodnie z zamysłem autorów metody przyjęto, że wyniki metryczne wykazują trzy rodzaje potencjalnych tendencji: 
- tendencje pozytywne (wynik 5, 4 pkt. - potwierdzenie pozytywnej tendencji w odniesieniu do tezy sugerowanej w itemie);

- tendencje ambiwalentne (wynik 3 pkt.);

- tendencje negatywne (wynik 2 i 1 pkt. - potwierdzenie negatywnej tendencji w odniesieniu do tezy sugerowanej w itemie).

\section{Badana grupa}

Grupę badanych stanowi 19 osób, które są uczestnikami duszpasterstwa osób żyjących w niesakramentalnych związkach małżeńskich (10 kobiet i 9 mężczyzn). Rozpiętość wieku wynosi od 39 do 71 lat - z czego wiek czterech osób można przyporządkować etapowi religijności spełnionej, a wiek pozostałych - etapowi religijności eschatologicznej. Osiem z badanych osób posiada wykształcenie średnie, a jedenaście wyższe. Wśród badanych pięć osób jest czynnych zawodowo, pozostali są na emeryturze. Badane osoby różnią się też stanem cywilnym, nie wszystkie prawnie zawarły ponowny związek cywilny. Trzy osoby są stanu wolnego (przebywają w związku, ale bez ślubu cywilnego). Zdecydowana większość ankietowanych posiada dzieci. Tylko trójka z nich jest bezdzietna. Dwanaście osób jako trudne wydarzenie życiowe podaje rozpad małżeństwa. Wszyscy badani deklarują się jako osoby wierzące. Dobrowolnie przynależą do grupy parafialnej. Dla dziesięciu osób życiowe plany i zainteresowania to turystyka i podróże. Często piszą o pielgrzymkach do miejsc świętych. Być może związane jest to z większą ilością czasu, przemyśleniami, dłuższym czasem modlitwy, a także analizą dotychczasowego życia. Wszyscy badani systematycznie uczęszczają na organizowane przez Duszpasterstwo Niesakramentalnych Związków Małżeńskich spotkania trzeciopiątkowe, a także biorą czynny udział w wydarzeniach Kościoła. 


\section{Wyniki}

Uzyskane wyniki świadczą o wysokim zaangażowaniu religijnym badanych. $\mathrm{Na} 19$ osób 8 uzyskało bardzo wysoki wynik globalny, 9 wysoki, a 2 osoby wynik średni. Sugeruje to, iż autentyczna potrzeba wiary domaga się realizacji nawet w sytuacji braku możliwości pełnego życia religijnego. Nie oznacza to jednak, że nie nadaje to religijności tych osób pewnych charakterystycznych cech.

Stwierdzone u badanych ambiwalentne lub negatywne tendencje zaznaczyły się szczególnie wyraźnie w parametrach U c zuć religijnych (20 itemów), w For mach wyznania wiary (20 itemów), w Moralności religijnej (18 itemów) orazw parametrze Decyzji religijn y c h (16 itemów). Można więc przyjąć, że układ tych czterech parametrów jest charakterystyczny dla badanej grupy, a swoisty stan uczuć i moralności religijnej decyduje o podejmowanych decyzjach i formach odniesienia do Boga, a tym samym do własnego życia i siebie.

Globalny poziom religijności zdecydowanie różnicuje uzyskane wyniki. Najmniej niekorzystnych tendencji stwierdzono u osób o bardzo wysokim poziomie religijności. Co więcej, wyniki dwóch osób z tego poziomu nie zawierały ich nawet w tych itemach, w których stwierdzono je u wszystkich badanych (parametr Praktyki religijne, item (100): „Zasadniczo nie przystępuję do Komunii Świętej” iitem(91): „Unikam przystępowania do sakramentu pokuty" -stwierdzono tu zaprzeczenie). Nasuwa to pytanie, czy aby ze względów religijnych osoby te nie zdecydowały się na formę „białego małżeństwa”. Jeżeli tak, to dowodziłoby to zdecydowanie prymarnej roli religijności w ich życiu.

Okazuje się również, że najwięcej niepożądanych wyników stwierdzono u osób nie, jak można by przypuszczać, z wynikiem najniższym z uzyskanych, a więc średnim, ale z wysokim. Sugeruje to istnienie dylematu pomiędzy wysokim jednak zaangażowaniem religijnym a sytuacją życia. Natomiast niższy poziom religijności prawdopodobnie pozwala łagodzić istniejące konflikty po prostu brakami w jej zakresie. 
Punktem wyjścia dla dalszej analizy będzie więc grupa z wysokim wynikiem globalnym, czyli 9 z 19 badanych (2 mężczyzn i 7 kobiet). Itemy, w których tendencje ambiwalentne lub negatywne pojawiły się więcej niż u jednej osoby, zaznaczono wykrzyknikiem (!).

W tej grupie najwięcej ambiwalencji i tendencji negatywnych stwierdzonow parametrze Moralność religijna, witemach:

(111) (!). Osobiste dylematy moralne rozwiązuję bez odwoływania się do nauczania Kościoła.

(115) (!). Żyję zgodnie z Dekalogiem.

(116) (!). Moją wiedzę na temat moralności czerpię z nauczania Kościoła.

(117) (!). Nie akceptuję stanowiska Kościoła odnośnie do niektórych problemów moralnych.

(118) (!). Nie czuję się winny przed Bogiem, gdy przekraczam zasady moralne.

(126) (!). Nie odczuwam wstydu przed Bogiem, gdy naruszam zasady moralne.

(130) (!). Społeczne dylematy moralne rozpatruję bez uwzględniania nauczania Kościoła.

(131) (!). Gdy przeżywam dylematy moralne nie odwołuje się do Boga.

(119). W moim życiu nie kieruję się Dekalogiem.

(121). Nie proszę o wybaczenie kogoś, do kogo mam żal.

(122). Bóg daje mi odwagę do przepraszania za wyrządzane krzywdy.

(128). Modlę się za tych, którzy mnie skrzywdzili.

(132). Gdy występują wątpliwości moralne, przystępuję do sakramentu pokuty.

Wskazuje to na istnienie rozdźwięku pomiędzy własną moralnością a nauczaniem Kościoła i Dekalogiem. Stwierdzone osłabienie poczucia winy i wstydu względem Boga może sugerować, że sytuacja życia badanych nie zawsze wynikała $\mathrm{z}$ ich niemoralnych intencji, a była w ich perspektywie z różnych względów życiową koniecznością. Stąd najpewniej tendencje 
do kształtowania „własnej moralności” pomimo bycia osobą wierzącą i praktykującą.

W parametrze Formy wyznania wiary niepożądane tendencje stwierdzono w itemach:

(160) (!). Nie utożsamiam się z Jezusem Chrystusem.

(168) (!). Moje zachowanie wypływa z żywej wiary.

(173) (!). Moja wiara nie przenika mojego codziennego życia.

(174) (!). W wydarzeniach mojego życia za mało współpracuję z Bogiem.

(175) (!). W sytuacjach trudnych nie dostrzegam obecności Boga.

(161). Uważam, że jakość życia zależy od wiary w Boga.

(162). Nie dążę do świętości.

(164). Moja wiara nakłania mnie do wykonania dla Boga czegoś trudnego.

(165). Moja wiara nie przejawia się w gotowości do ofiary z mojego życia.

(166). Moja wiara wyznacza kierunek podejmowanych przeze mnie działań religijnych.

Przy istniejącej potrzebie życia religijnego widzimy jednak, że osoby z wysokim wynikiem globalnym nie mają pełnego poczucia przenikania życia przez wiarę, poczucia bliskości z Bogiem „na co dzień”. Jest to szczególnie widoczne w sytuacjach trudnych. Życie z wiarą staje się więc jakby idealną, ale nieosiągalną formą egzystencji, którą dodatkowo utrudniają problemy życia.

Parametr Uczucia religijne:

(25) (!). Gdy Bóg nie wysłuchuje moich modlitw, odczuwam bunt przeciw Niemu.

(26) (!). Przeżywam rozpacz na myśl o Sądzie Ostatecznym.

(34) (!). Bóg wywołuje we mnie niepokój.

(37) (!). Osobista więź z Bogiem wpływa na moją miłość do nieprzyjaciół.

(39) (!). Więź z Bogiem wzbudza we mnie trwogę.

(40) (!). Przeżywam ufność na myśl o Sądzie Ostatecznym.

(43) (!). Moje życie religijne napełnia mnie lękiem. 
(44). Pismo Święte uczy mnie, jak być szczęśliwym.

(30). Nie jestem wdzięczny Bogu za wydarzenia mojego życia.

(36). Śmierć dziecka wywołuje we mnie bunt wobec Boga.

W uczuciach religijnych zaznacza się lęk (w tym także eschatologiczny), niepokój, niepewność, a nawet bunt, świadczący o trudnościach w zaufaniu przy jednoczesnej potrzebie doświadczenia bliskości i wsparcia.

Parametr Decyzje religijne:

(53) (!). Przy ważnych wyborach zadaję sobie pytanie o ostateczny cel mojego życia.

(55) (!). Podjąłem ważną decyzję, że będę naśladować Jezusa Chrystusa.

(56) (!). Nie odczytuję swojego życia w perspektywie planów Bożych.

(59) (!). W ważnych wyborach nie odwołuję się do zasad religijnych.

(60) (!). Gdy życie niweczy moje plany, stawiam sobie pytanie o ostateczny cel mojego życia.

(45). Nie jestem zadowolony z wypełniania się planów Bożych w moim życiu.

(65). W moich wyborach politycznych nie uwzględniam nauczania Kościoła.

W sytuacji, gdy religijność jest autentyczną treścią ludzkiej egzystencji, decyzje religijne zrównują się z decyzjami życiowymi. Układ wyników wskazuje na niepewność co do trafności życiowego wyboru, jak i na niepewność co do ostatecznego jego sensu.

W pozostałych parametrach również odnajdujemy pewne specyficzne tendencje.

W parametrze Doświadczenie religijne:

(133) (!). Nie doświadczam więzi z Jezusem Chrystusem.

(140). W najtrudniejszym momencie życia nie doświadczam interwencji Boga.

(142). W beznadziejnej sytuacji nie doświadczam pomocy Boga. 
(149). Doświadczam głębokiej realności Boga.

Doświadczenie obecności Boga w życiu jest niejednoznaczne. Zostaje pytanie, czy to przez sposób percepcji własnej sytuacji, czy też może przez za małe otwarcie się i wiążące się z tym problemy w pełnym zaufaniu, zwłaszcza w sytuacji trudnej.

W parametrze Św ia do mość re ligijn a tendencji ambiwalentnych i negatywnych stwierdzono najmniej i tylko w poniższych itemach (były to wyłącznie odpowiedzi jednostkowe) i zdają się potwierdzać stwierdzone wcześniej trudności w uf nym otwarciu się tak na Boga, jak i na wymagania wiary.

(6). Chciałbym mieć więcej pewności w wierze.

(14). Nie akceptuję nauczania Kościoła.

(17). Bóg wie, co jest dla mnie pożyteczne.

(22). Wymagania stawiane przez Kościół utrudniają mi funkcjonowanie we współczesnym świecie.

Kilka niekorzystnych i jednostkowych odpowiedzi stwierdzono również w parametrze Więź ze wspólnotą osób wierzących, gdzie powiela się kwestia zaufania i pewności w odniesieniu do nauczania Kościoła:

(68). Kościół wprowadza mnie w życie wiary głównie poprzez sakramenty.

(72). Uważam, że wspólnotą Kościoła kieruje Duch Święty.

(83). Nie mam zaufania do wspólnoty osób wierzących.

W parametrze Praktyki religijne mamy już wyłącznie odbicie sytuacji życia badanych:

(100) (!). Zasadniczo nie przystępuję do Komunii Świętej.

(91). Unikam przystępowania do sakramentu pokuty.

Wśród pozostałych badanych tylko dwaj mężczyźni uzyskali średni globalny poziom religijności. Ich odpowiedzi rzadko były zdecydowane (punktacja 5), najczęściej pojawiały się tendencje ambiwaletne (punktacja 3) lub tendencje negatywne wiążące się z niepewnością (punktacja 2). 
W parametrze Uczucia religi i ne tendencje te zaznaczyły się szczególnie w itemach:

(24). Nadzieja pokładana w Jezusie Chrystusie daje mi pełne szczęście.

(25). Gdy Bóg nie wysłuchuje moich modlitw, odczuwam bunt przeciw Niemu.

(26). Przeżywam rozpacz na myśl o Sądzie Ostatecznym.

(27). Bycie chrześcijaninem wzbudza we mnie poczucie godności.

(28). Uważam, że Bóg mnie nie kocha.

(30). Nie jestem wdzięczny Bogu za wydarzenia mojego życia.

(33). Nadzieja religijna podtrzymuje moje życie.

(34). Bóg wywołuje we mnie niepokój.

(43). Moje życie religijne napełnia mnie lękiem.

(44). Pismo Święte uczy mnie, jak być szczęśliwym.

W parametrze Świadomość religijna:

(14) (!). Nie akceptuję nauczania Kościoła.

(4). Wiedza religijna nie pomaga mi w rozumieniu świata.

(5). Cierpienie ma sens dla mnie wtedy, gdy odnoszę je do Boga.

(7). Moje życie ma sens także bez Boga.

(10). Moja wiara w Boga opiera się na czymś mało pewnym.

(12). Uważam, że Bóg nie interesuje się człowiekiem.

(22). Wymagania stawiane przez Kościół utrudniają mi funkcjonowanie we współczesnym świecie.

W parametrze Formy wyznania wiary:

(169). Uważam, że jakość życia nie zależy od wiary w Boga.

(170). W sytuacjach życiowo trudnych nie uzewnętrzniam swojej wiary.

(173). Moja wiara nie przenika mojego codziennego życia.

(174). W wydarzeniach mojego życia za mało współpracuję z Bogiem.

(175). W sytuacjach trudnych nie dostrzegam obecności Boga.

W parametrze Doświadczenie religijne:

(133). Nie doświadczam więzi z Jezusem Chrystusem. 
(135). Nie doświadczam więzi ze wspólnotą Kościoła.

(136). Nie zawierzam Bogu swojego życia.

(147). Nawet w Kościele nie doświadczam więzi z Jezusem Chrystusem. W parametrze Moralność religijna:

(116). Moją wiedzę na temat moralności czerpię z nauczania Kościoła. (118). Nie czuję się winny przed Bogiem, gdy przekraczam zasady moralne.

(119). W moim życiu nie kieruję się Dekalogiem.

W parametrze Decyzje religijne:

(45). Nie jestem zadowolony z wypełniania się planów Bożych w moim życiu.

(50). W dokonywanych wyborach nie uwzględniam stanowiska Kościoła katolickiego.

W parametrze Praktyki religijne:

(91). Unikam przystępowania do sakramentu pokuty.

(100). Zasadniczo nie przystępuję do Komunii Świętej.

Zauważamy tu tendencje, które zaznaczyły się już u osób z wynikiem wysokim, z jednoczesnym wzmocnieniem braku zaufania i oparcia. Dodatkowo stwierdzamy osłabienie poczucia winy i wstydu względem Boga, przy jednoczesnej niezgodzie na wymogi nauczania Kościoła, co może wynikać z mniejszego znaczenia religijności w życiu tej grupy badanych albo po prostu $z$ istniejących w niej braków. Należy dodać, że osoby ze średnim wynikiem globalnym uzyskały jednocześnie najwięcej negatywnych i ambiwalentnych tendencji w parametrze Świadomość religijna, przy czym stwierdzono, że im wyższy był tu poziom świadomości religijnej, tym więcej pojawiało się dylematów moralnych i niepewności eschatologicznej, a także niepewności wobec nauczania Kościoła.

Natomiast osoby z wynikiem bardzo wysokim (5 mężczyzn i 3 kobiety) przeważnie nie wykazywały niepewności lub niezdecydowania, a do 
większości itemów odnosiły się jednoznacznie (zakreślając na skali 1 lub 5). Tym bardziej interesują więc itemy, w których pojawiły się tendencje ambiwalentne lub negatywne. Stwierdzono je w Decyzjach religijnych i Formach wyznania wiary.

W zakresie decyzji religijnych odnosi się to do jednostkowych stwierdzeń w itemach:

(45). Nie jestem zadowolony z wypełniania się planów Bożych w moim życiu.

(50). W dokonywanych wyborach nie uwzględniam stanowiska Kościoła katolickiego.

(51). Moje decyzje w sytuacjach trudnych potwierdzają wierność Bogu.

(53). Przy ważnych wyborach zadaję sobie pytanie o ostateczny cel mojego życia.

(57). Przy wyborach życiowo doniosłych zasięgam rady osób głęboko wierzących.

W parametrze Formy wyznania wiary zauważamy w tej grupie niekorzystne tendencje w itemach:

(161). Uważam, że jakość życia zależy od wiary w Boga.

(164). Moja wiara nakłania mnie do wykonania dla Boga czegoś trudnego.

(173). Moja wiara nie przenika mojego codziennego życia.

(174). W wydarzeniach mojego życia za mało współpracuję z Bogiem.

(175). W sytuacjach trudnych nie dostrzegam obecności Boga.

W parametrze Praktyki religijne:

(100) (!). Zasadniczo nie przystępuję do Komunii Świętej.

(91). (!). Unikam przystępowania do sakramentu pokuty.

(86). Nie mam pragnienia głoszenia Ewangelii.

W parametrze Moralność religijna:

(115). Żyję zgodnie z Dekalogiem.

(132). Gdy występują wątpliwości moralne, przystępuję do sakramentu pokuty. 
W parametrze Doświadczenie religijne:

(151). W momencie cierpienia nie przeżywam więzi z Jezusem Chrystusem.

W parametrze Uczucia religijne:

(43). Moje życie religijne napełnia mnie lękiem.

Wyniki wydają się oddawać pełne zrozumienie własnej sytuacji moralnej. Badani odczuwają wstyd, winę a nawet lęk i raczej jednoznacznie traktują swe życie małżeńskie jako niezgodne z nauczaniem Kościoła, które respektują. Należy zwrócić jednak uwagę na fakt, że zgoda na życie bez sakramentów wiąże się tu z bardzo wysokim poziomem religijności testowej, która najpewniej jest tak istotnym aspektem życia, że nawet trwanie w stanie grzechu ciężkiego nie osłabia potrzeby relacji do Boga. Potwierdzają to wyniki w parametrze Świ d o m ości religijnej, gdzie w tej grupie nie stwierdzono ani jednej niepożądanej tendencji. Można więc przyjąć, że im wyższy poziom religijności, tym większa trafność w ocenie własnego życia, a co za tym idzie, mniej dylematów względem przyjętego systemu moralnego.

I jeszcze zestawienie itemów, w których tendencje ambiwalentne lub negatywne pojawiły się we wszystkich trzech grupach badanych (z globalnym wynikiem: bardzo wysokim, wysokim i średnim):

W zakresie uczuć religijnych:

(43) (!). Moje życie religijne napełnia mnie lękiem.

W zakresie moralności religijnej:

(115) (!). Żyję zgodnie z Dekalogiem.

W formach wyznania wiary:

F (173) (!). Moja wiara nie przenika mojego codziennego życia.

F (174)(!). W wydarzeniach mojego życia za mało współpracuję z Bogiem.

$\mathrm{F}(175)$ (!).W sytuacjach trudnych nie dostrzegam obecności Boga.

W decyzjach religijnych:

(45) (!). Nie jestem zadowolony z wypełniania się planów Bożych w moim życiu. 
W odpowiedziach zauważalny jest nie tyle respekt, co niepokój i niepewność. Osłabione poczucie bliskości Boga tłumaczone jest własnymi brakami w otwarciu się na tę relację, zwłaszcza w sytuacjach trudnych.

Układ tendencji ambiwalentnych lub negatywnych świadczy także o wyraźnych wątpliwościach mimo zaangażowania religijnego (najczęściej wysokiego). Można więc przypuszczać, że istnieje tu rozdźwięk pomiędzy bardzo znaczącą rolą wyznawanej wiary a praktyką życiową. Pogodzenie tego w życiu staje się dla niektórych badanych trudnym zadaniem. W sensie psychologicznym mamy tu konflikt pomiędzy tendencją życiowo doniosłą (wiarą) a praktyką życiową. Powoduje to powstanie konfliktu, w którym badani zmuszeni są trwać pomimo rozbudowanych potrzeb życia religijnego. Pozyskane dodatkowe informacje o ścieżce ich życia sugerują, że zaistniała negatywna sytuacja (w ich ocenie) nie wynikała ze złej woli, a tylko z niemożności poradzenia sobie z nieudanym pierwszym związkiem sakramentalnym. To jednakże dla osoby wierzącej ma swe konsekwencje w postaci odstąpienia od reguł wiary katolickiej oraz wątpliwości w odniesieniu do sensu tego, co je spotkało. Przejawia się tu niepewność co do słuszności własnego postępowania, zwłaszcza w perspektywie eschatologicznej, choć z powodów czysto życiowych wydaje się ono zasadne.

Dobra relacja do Boga jest jednak dla badanych tak ważna, że pomimo wszystko starają się ją realizować. Można więc chyba mówić tu o autentycznym, choć swoistym zaangażowaniu religijnym, którego wartością jest trwanie mimo przeciwności i osłabionego zaufania. Rodzi się pytanie o regulacyjną funkcję tak realizowanej wiary. Patrząc na uzyskane wyniki, wydaje się, że w kontekście nasilania się konfliktów maleje jej rola porządkująca i uzasadniająca, skutkiem czego kształtuje się własna moralność przy jednocześnie wyraźnej potrzebie odczuwania obecności Boga w życiu i otwarciu się na tę relację. Być może więc kwestia ufności/zawierzenia w relacji człowiek-Bóg (wyniki w parametrze Formy wy znania wiary) jest tym czymś, co w sytuacji badanych najbardziej warte jest wsparcia. 


\section{Podsumowanie i wnioski}

W badanej grupie stwierdzono wysoką potrzebę życia religijnego przy jednoczesnej niemożności pełnej jej realizacji zgodnie z zasadami wiary katolickiej. I choć badani najczęściej interpretują tę sytuację jako niejako „wymuszoną” przez okoliczności, to w ostatecznym rozrachunku i tak pozostaje ona efektem ich dobrowolnego wyboru. W ich religijności wyraźnie zaznaczają się więc konsekwencje dylematu: uznane zasady religijności - realizowana praktyka religijna i manifestują się głównie:

- w niepewności co do trafności życiowego wyboru, jak i w niepewności co do ostatecznego jego sensu;

- w rozdźwięku pomiędzy własną moralnością a Dekalogiem przy jednoczesnym osłabieniu poczucia winy i wstydu względem Boga;

- w wątpliwościach względem nauczania Kościoła;

- w lęku (w tym także eschatologicznym), niepokoju, niepewności, a nawet w buncie świadczącym o trudnościach w zaufaniu;

- w trudnościach w otwarciu się na Boga przy jednoczesnej potrzebie doświadczenia Jego bliskości i wsparcia;

- w braku poczucia przenikania całego życia przez wiarę;

- w niejednoznacznym doświadczaniu Boga i Jego obecności w życiu, szczególnie w sytuacjach trudnych.

Należy zaznaczyć, że bardzo wysoki ogólny poziom religijności (w tym szczególnie bardzo wysoki poziom świad o mości religijnej) wyraźnie osłabia nasilenie tych tendencji, co świadczy o wysokiej regulacyjnej funkcji testowo dojrzałej religijności, która pozwala na osłabianie lub niwelowanie nawet tak trudnych dylematów.

Przeprowadzone badania sugerują również, że istniejący rozdźwięk pomiędzy uznanymi zasadami religijności a swoiście realizowaną praktyką religijną staje się szczególnie znaczący w późniejszych okresach życia. W badanej grupie decyzje o przystąpieniu do Duszpasterstwa Niesakramentalnych 
Związków Małżeńskich zapadły na przełomie potencjalnych okresów religijności spełnionej i religijności eschatologicznej. Jak podaje Czesław Walesa (Walesa, 2005, s. 80-81), najważniejszą możliwością tych etapów jest osiągnięcie religijności dojrzałej. Odbywa się to poprzez pogłębiające się uwrażliwienie religijne, chęć intymnej i autentycznej (a nie tylko instrumentalnej) relacji z Bogiem, przenikającą życie potrzebę modlitwy. W okresie religijności eschatologicznej (od ok. 60 r.ż.) łączy się to ponadto z potrzebą osiągniecia stanu scalenia, harmonii i sensu w odniesieniu do całego życia, w tym także antycypowanego. Potrzeba osiągnięcia integralności egzystencjalnej uaktywnia mechanikę kontroli wtórnej, polegającą na weryfikacji zdarzeń życia, co może doprowadzić do rewizji ich sensu, np. w odniesieniu do doświadczanego cierpienia lub niezrozumienia. Może dojść wtedy do znaczących decyzji zmieniających dotychczasowy kierunek życia (np. do nawrócenia) (Tatala, Walesa, 2016, s. 26-27).

Konkludując, można by przyjać, że mocna potrzeba życia religijnego, nawet w połączeniu z sytuacją uniemożliwiającą jego pełnię, nie blokuje rozwoju religijności. Sytuacja taka stanowi raczej rodzaj nienormatywnego czynnika rozwoju, przy działaniu którego religijność nie zanika, a trwa i podlega dalszej zmienności, co uwidacznia się choćby w efektach udziału w odpowiednich formach duszpasterskich. Stałe pozostaje otwarcie się na doświadczenie religijne i poszukiwanie go wraz ze zdecydowaną do tego gotowością. Być może dodatkowo wzmacnia to sytuacja deprywacji, kryzysu, dojmującego od lat braku w połączeniu ze specyfiką finalnych okresów w rozwoju religijności.

Jak czytamy w tekstach duszpasterskich, proces nawracania wymaga tak czasu, jak i doświadczania własnej słabości i niewystarczalności. Stąd w stanowisku Jana Pawła II mowa o Łasce, która stopniowo przenika. Papież zaznacza przy tym, że by tak mogło się stać, konieczne jest odpowiednie środowisko (FC 84). Przeprowadzone badania potwierdzają, że otwarcie się Kościoła na osoby niemogące w pełni realizować swej religijności (przy 
oczywistym zachowaniu prawd religijnych) jest jak najbardziej zasadne. Cytując: „niektórzy wraz z upływem czasu odkrywają ze zdumieniem, że z pomocą Łaski Bożej możliwe staje się to, co wydawało się kiedyś niemożliwe"4.

\section{Bibliografia}

Boguszewski R. (2014). Komunikat Centrum Badania Opinii Społecznej. Warszawa. Goszczyńska-Górska A. (2004). Miej miłosierdzie dla nas. O związach niesakramentalnych. Kraków.

Góralczyk P. (1995). Powtórne związki matżenskie w teologicznym i etycznym świetle. Ząbki.

Grzybowski J. (2008). Niesakramentalna mitość, wierność i uczciwość. Częstochowa.

Ostrowski M. (2011). Wy jesteście w Kościele. Duszpasterstwo Matżeństw Niesakramentalnych. Poznań.

Rydz E. (2014). Tendencje rozwojowe religijności młodych dorostych. Lublin.

Rydz E., Walesa C., Tatala M. (2017). Structure and level of religiosity test. „Polish Psychological Bulletin” 48, s. 20-27.

Tatala M., Walesa C. (2016). Religijne decyzje życiowo doniosłe w okresie wczesnej, średniej i późnej dorosłości. W: Horyzonty psychologii, t. VI: Artykuty naukowe. Lublin.

Tettamanzi D. (2006). Nikt was nie odrzuca. Pelplin.

Tutak J. M. (2010). Religijnośćpolska:próba syntezy. „Warszawskie Studia Pastoralne” 12, s. 108-112.

Walesa C. (2005). Rozwój religijności człowieka, t. I: Dziecko. Lublin.

Wermter W. (2009). Związek niesakramentalny-jak w nim wytrzymać. Częstochowa.

4 https://www.deon.pl/slub/duchowosc/art,67,katolik-w-zwiazku-niesakramentalnym.html. 


\section{Źródła}

(FC) Jan Paweł II. (1981). Adhortacja apostolska „Familiaris Consortio” o zadaniach rodziny chrześcijańskiej w śrwiecie respótczesnym. Watykan.

(RP) Jan Paweł II. (1984). Adhortacja apostolska „Reconciliatio et poenitentia” o pojednanin i pokucie w dzisiejszym postannictwie Kościoła. Watykan.

(KKK) Katechizm Kościota Katolickiego. (1994). Poznań.

\section{Literatura uzupełniająca}

https://www.deon.pl/slub/duchowosc/art,67,katolik-w-zwiazku-niesakramentalnym.html. 


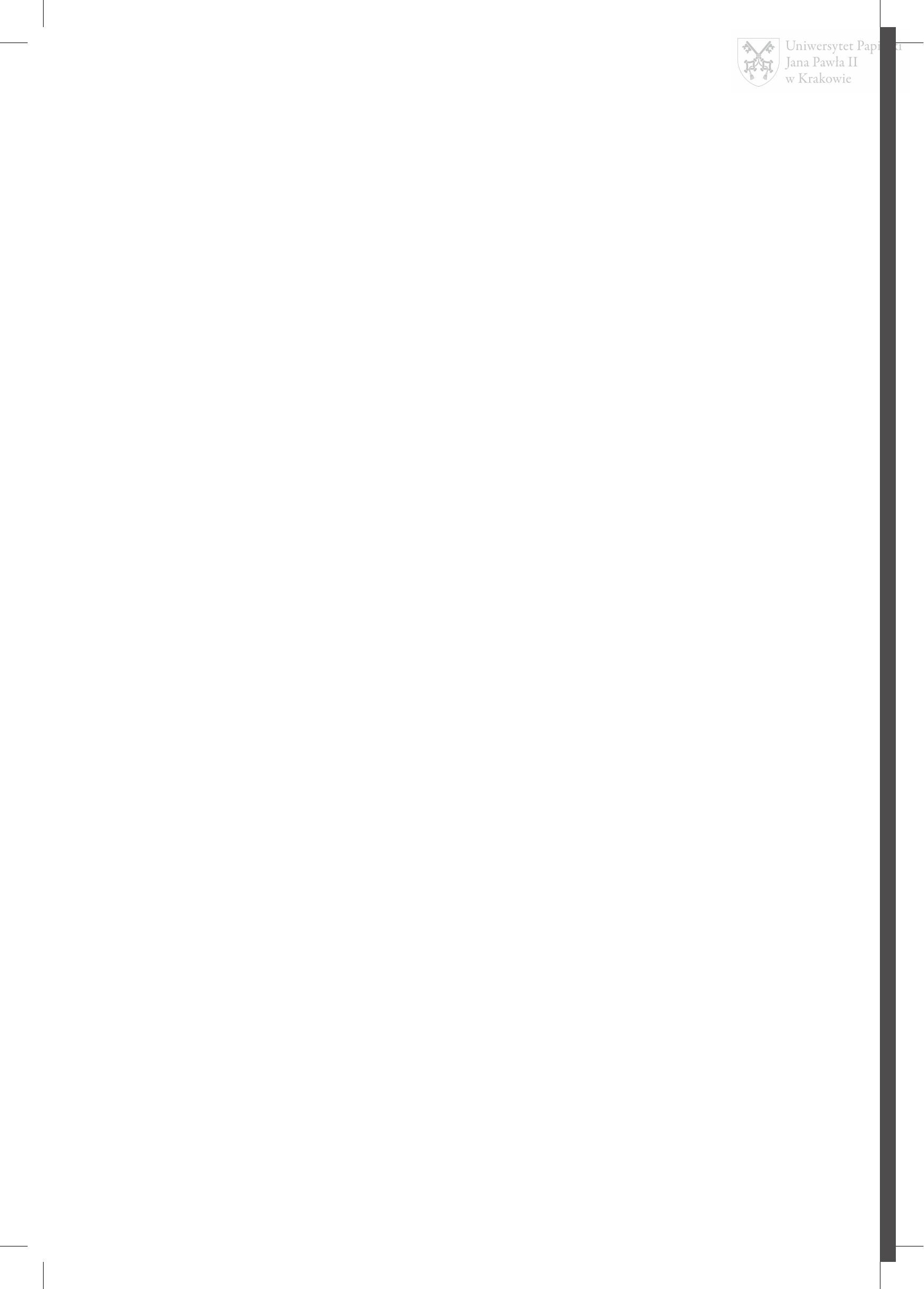

